Revista Tecnologia e Sociedade, Curitiba, v. 11, n. 22, 2015

Edição Especial XII Encontro Nacional de Engenharia e Desenvolvimento Social

ISSN (versão online): 1984-3526

ISSN (versão impressa): 1809-0044

\title{
Políticas de agroindustrialização em assentamentos da reforma agrária: uma análise do dialogo entre a prática das cooperativas do MST e as políticas governamentais
}

\author{
Agro-industrialization policies on agrarian reform settlements: an analysis of the \\ dialogue between the practice of the MST cooperatives and government policies
}

\author{
Farid Eid ${ }^{1}$ \\ Felipe Addor ${ }^{2}$ \\ Caio Luis Chiariello ${ }^{3}$ \\ Camila Rolim Laricchia ${ }^{4}$ \\ Alex Kawakami ${ }^{5}$
}

Artigo recebido para publicação em jun./2015 e aceito para publicação em jun./2015

\begin{abstract}
RESUMO
Neste artigo, apresentamos uma reflexão sobre a política de apoio à agroindustrialização de assentamentos da reforma agrária no Brasil. Primeiro, trazemos uma discussão sobre cadeias produtivas solidárias, que orientam a estratégia de fortalecimento dos assentamentos com projetos para além da produção agrícola, mostrando a importância de se consolidar atividades de beneficiamento e comercialização que propiciem maior geração de renda e melhores condições de trabalho aos agricultores. Em seguida, discorremos sobre as primeiras estratégias de apoio à agroindústria em assentamentos, que nos remete à década de 1990 e às experiências das CPA (cooperativas de produção agropecuária) ligadas ao MST, e apresentamos duas experiências que se destacaram naquela época: Cooperunião e Copavi. Depois, apresentamos as diferentes propostas de políticas públicas desenvolvidas nas últimas décadas e que tem como foco o fomento à agroindustrialização para pequenos agricultores. Por fim, trazemos a experiência de diálogo com a cooperativa Coopaterra, no Rio de Janeiro, que com o apoio da UFRJ, busca estruturar-se para poder concorrer a um financiamento para a agroindústria através do programa Terra Forte, do governo federal. Esse caso permite vislumbrar a dificuldade de articulação entre as exigências burocráticas dos editais que visam apoiar os assentamentos.
\end{abstract}

Palavras-chave: cooperativas; políticas públicas; reforma agraria.

\begin{abstract}
\footnotetext{
${ }^{1}$ Economista e Administrador. fe9998@gmail.com

2 Engenheiro de Produção. faddor@gmail.com

3 Economista. caiochiariello@ufgd.edu.br

4 Engenheira de Produção. camila laricchia@hotmail.com

${ }^{5}$ Engenheiro Agônomo. alexkawakami@gmail.com
}

In this paper is presented a reflection about the politics of support to the agribusiness in the small properties arising from reform land in Brazil. In the first place, we bring out a discussion about solidary production chains, which guides the strategy of strenghtnening of the small land setllements, with projects that go beyond de mere primary production, showing the importance of setting the processing and dealing activities, which bring greater income and better working conditions to the small farmers. After that, we commented about the very first strategies to support the agribusiness in reformed land which lead us back to the 1990's and the experiences with the companies knowed as CPA in portuguese, which stands for Livestock-Agribusiness Cooperative Companies related to the popular movement MST, pointing at two particular cases: Coperunião e Copavi. Then, we present the different proposals of public policy developed in the last decades aiming the improving of small 
Revista Tecnologia e Sociedade, Curitiba, v. 11, n. 22, 2015

Edição Especial XII Encontro Nacional de Engenharia e Desenvolvimento Social

ISSN (versão online): 1984-3526

ISSN (versão impressa): 1809-0044

properties agroindustrialization. Finally, we arise an experiense of a dialogue between Copaterra in Rio de Janeiro and the UFRJ (Federal University of Rio de Janeiro) when the company is working on structuring itself in such a way it could enrol to obtain a public financing from a Federal Governament Program called Terraforte, highlighting the difficult process of fitting in burocratic requirements.

Key-words: cooperatives; public policies; reform land.

\section{INTRODUÇÃO}

O tema da agroindustrialização já vem há algumas décadas sendo construído como uma das agendas mais importantes para a sustentabilidade de um projeto político de fortalecimento das atividades produtivas familiares no campo, bem como de garantia de melhores condições de vidas aos seus trabalhadores. Os movimentos sociais do campo já sabem, por experimentação própria, que a simples destinação de terras aos trabalhadores rurais sem terra não representa a garantia de condições efetivas de mudanças sociais. Primeiro, porque são inúmeros os casos de distribuição de terra, no âmbito da reforma agrária, em contextos quase inviáveis de produção, seja pela baixa qualidade da terra para a agricultura, seja pelas dificuldades estruturais de plantio e comercialização geradas por vários fatores, como longas distâncias do assentamento de qualquer aglomerado urbano, estrutura viárias precárias, acesso inadequado ou inexistente à rede elétrica.

Segundo, porque as dificuldades enfrentadas pelos pequenos agricultores, em concorrência direta com grandes conglomerados alimentícios, tornam cada vez mais difícil uma sobrevivência digna apenas com o plantio. A dependência de atravessadores é uma situação frequente e incontornável, levando, em geral, a uma situação de grande exploração dos agricultores, que vendem seus produtos a um preço muito baixo.

Nesse cenário, vem ganhando cada vez mais força a demanda por políticas que fortaleçam as atividades de agregação de valor aos produtos agrícolas, sendo o caminho mais efetivo e com maior potencial o de implantar agroindústrias nos assentamentos. O que está por trás dessa estratégia é uma reconfiguração da cadeia produtiva desses produtos, de forma que se permita que o produtor possa ter o domínio de um maior número de etapas desta cadeia. Esta perspectiva permite, principalmente quando falamos no âmbito dos movimentos sociais rurais, pensar uma cadeia produtiva mais solidária, promovendo uma relação mais saudável entre 
Revista Tecnologia e Sociedade, Curitiba, v. 11, n. 22, 2015

Edição Especial XII Encontro Nacional de Engenharia e Desenvolvimento Social

ISSN (versão online): 1984-3526

ISSN (versão impressa): 1809-0044

seus diferentes elos e evitando um ambiente competitivo mesmo entre fornecedores e clientes.

Diferente do que pode ser apresentado por uma visão institucional, a política de fomento à agroindústria não advém de um iniciativa puramente governamental e nem nasceu nos últimos anos. Ela é consequência de uma construção de décadas e resultado de uma pressão dos movimentos sociais rurais, que já denotam há tempos a necessidade de melhor estruturar os processos produtivos dos assentamentos da reforma agrária. Neste artigo, apresentamos uma trajetória histórica desse fenômeno de consolidação de políticas voltadas à implantação de agroindústrias, tanto a partir de suas bases nas organizações da sociedade civil, com destaque para a luta do Movimento dos Trabalhadores Rurais Sem Terra (MST), quanto a partir do desenvolvimento de políticas públicas do governo federal direcionadas a essa estratégia.

A implantação de agroindústrias é uma das alternativas econômicas para a permanência dos agricultores familiares no meio rural. Oportuniza a inclusão social, a participação no desenvolvimento e a equidade, especialmente entre mulheres, os idosos e os jovens. No interior das cooperativas populares e empreendimentos de economia solidária no campo, a agroindustrialização está colocada como uma etapa de amadurecimento das iniciativas econômicas que tiveram início com a conquista da terra, assentamento de famílias, produção inicial para subsistência, produção direcionada para formação de excedente para comercialização, chegando à etapa agroindustrial para maior agregação de valor à produção coletiva.

Em Pimentel (2004), Eid et al (2006), Severino (2006), Vazzoler (2004), Chiariello (2008) e Christofolli (1998), esta transição da produção agrícola para a produção agroindustrial é apresentada como um processo de aprendizado, com avanços e retrocessos, pois adentrar nas estruturas de mercado para competir com empresas tradicionais levaram muitas cooperativas populares e empreendimentos solidários do campo a um tensionamento. Por um lado, há a necessidade de habilitar os trabalhadores associados a novas práticas produtivas, manuseio de novo ferramental, máquinas e equipamentos não usuais de seu cotidiano na execução das tarefas produtivas. Por outro lado, a urgência em fazer a gestão do empreendimento, basicamente incorporando as funções compras, processamento e vendas, ou seja, ligando o empreendimento às cadeias produtivas, demandou um 
Revista Tecnologia e Sociedade, Curitiba, v. 11, n. 22, 2015

Edição Especial XII Encontro Nacional de Engenharia e Desenvolvimento Social

ISSN (versão online): 1984-3526

ISSN (versão impressa): 1809-0044

aprimoramento das técnicas de gestão, manuseio também de instrumentos tecnológicos e relacionais para inserção nos mercados. Este processo, como sublinham os autores supracitados, demarcou o avanço de grande número de empreendimentos cooperativos nas atividades produtivas, mas também demarcou o esfacelamento de outras organizações de produção coletiva.

\section{O PAPEL INOVADOR DO MST E AS COOPERATIVAS DE PRODUÇÃo AGROPECUÁRIA}

Os movimentos sociais rurais no Brasil representam, atualmente, as principais forças de pressão da sociedade civil organizada junto ao Estado. Movimentos como o MST e o Movimento dos Pequenos Agricultores (MPA) sempre representaram uma escola de formação para lideranças populares. No entanto, além do aspecto da luta política, um desafio sempre presente para esses trabalhadores foi a questão da produção. Afinal, a luta pela reforma agrária ganha enorme força quando fica demonstrado que são os agricultores familiares, mesmo tendo uma parcela pequena da terra agricultável do país e pouco acesso a crédito, que produzem mais de $70 \%$ da alimentação dos brasileiros. ${ }^{6}$ A tabela abaixo resume o papel de cada tipo de produção no país:

\footnotetext{
${ }^{6}$ http://www2.planalto.gov.br/excluir-historico-nao-sera-migrado/agricultura-familiar-ja-produz-70-dos-alimentosconsumidos-no-mercado-interno-do-pais-informa-pepe-vargas.
} 


\section{Agricultura Camponesa}

Agronegócio

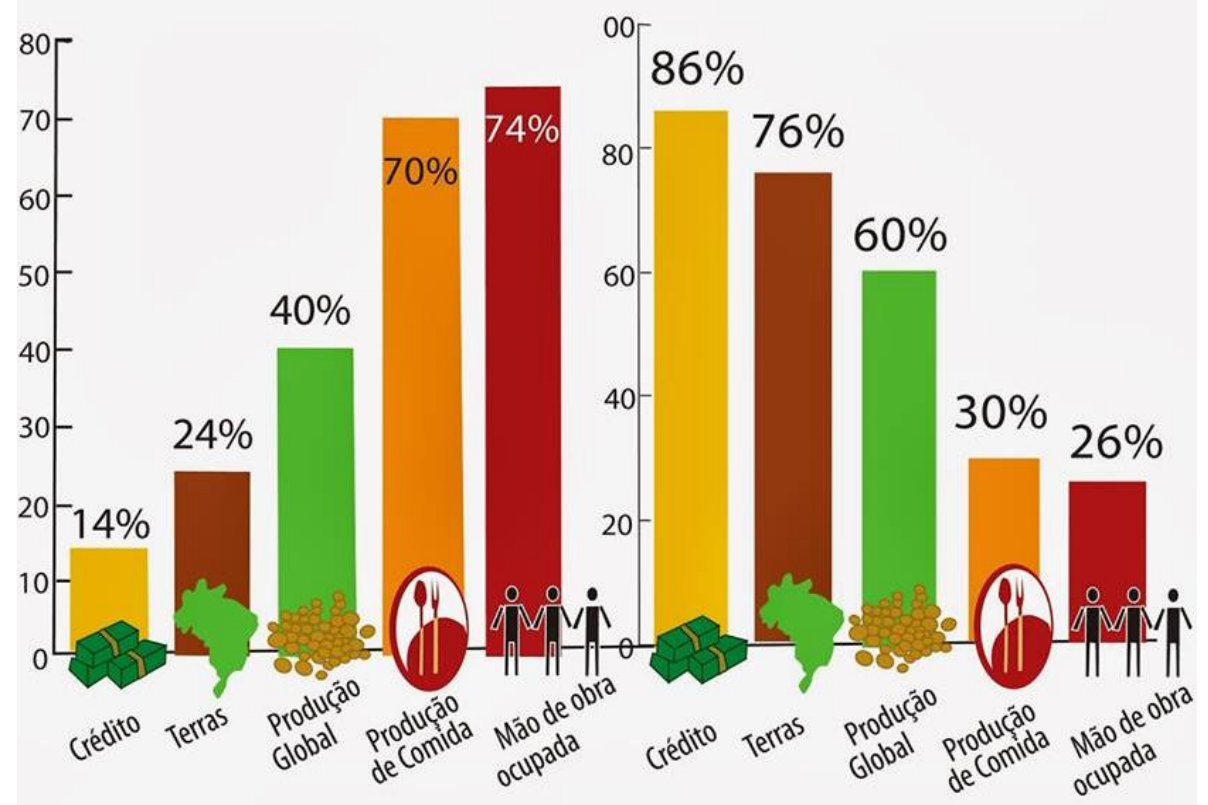

Fonte: Censo Agropecuário do IBGE/2006.

No âmbito produtivo, um princípio que perpassa a atuação dos movimentos sociais rurais é o da cooperação. Contrariando a perspectiva empreendedora individualista de busca de ganhos pessoais que orienta o desenvolvimento da economia capitalista, esses movimentos buscam fortalecer o trabalho coletivo, a divisão dos ganhos, a horizontalidade das decisões. Mormente organizados em cooperativas, os trabalhadores praticam o que ficou reconhecido como economia solidária, mostrando que uma prática coletiva e solidária garante um avanço mais efetivo e duradouro do grupo como um todo.

Na percepção do Movimento dos Trabalhadores Rurais Sem Terra (MST), a cooperação é um meio ou instrumento para realização das transformações sociais e para a melhoria permanente das condições de vida dos trabalhadores associados, superando as dificuldades que os assentados têm para sobreviver e competir no mercado através da exploração de seus lotes individuais com a força de trabalho familiar (DAL RI; VIEITEZ, 2008). As modalidades de cooperação praticadas pelos assentados diferem principalmente no que diz respeito à utilização da terra e dos meios de produção e à organização do trabalho e planejamento da produção. $\mathrm{A}$

\footnotetext{
${ }^{7}$ Disponível em: http://www.jornadaagroecologia.com.br/?p=1781
} 
Revista Tecnologia e Sociedade, Curitiba, v. 11, n. 22, 2015

Edição Especial XII Encontro Nacional de Engenharia e Desenvolvimento Social

ISSN (versão online): 1984-3526

ISSN (versão impressa): 1809-0044

organização para a cooperação encontrada nos assentamentos parte de pequenos núcleos familiares até a cooperação integral entre todos os assentados.

\section{O MST E A AGROINDUSTRIALIZAÇÃO: AS CPAs}

As experiências iniciais com implantação de cooperativas de produção agropecuária (CPA) através do MST ocorrem a partir de 1989. Em uma CPA, a terra permanece sob o controle coletivo, havendo o estímulo para a construção de agrovilas. O título de propriedade ou concessão de uso da terra pode estar em nome da CPA e os investimentos em meios de produção são controlados pela cooperativa. $\mathrm{Na}$ CPA, o patrimônio acumulado constitui fundos indivisíveis, trata-se de um patrimônio social que não pode ser requerido individualmente em caso de saída de sócios. A organização do trabalho se faz no interior de cada setor de atividade da cooperativa, respeitados os critérios de capacidade técnica e disponibilidade dos trabalhadores associados. O planejamento da produção é centralizado no coletivo, embasado em estudos técnicos e na adoção de linhas de atividades prioritárias.

Em junho de 1990, foi implantado o Sistema Cooperativista dos Assentados (SCA), como forma de organizar e aproximar as unidades do sistema de cooperativas do MST. O SCA passou a formular as linhas políticas para a organização da produção, sendo seu principal desafio a definição de estratégias de produção voltadas tanto para a subsistência quanto para o mercado, buscando tornar as cooperativas economicamente viáveis, mas distintas do modelo do cooperativismo tradicional (CONCRAB, 1996; VAZOLLER, 2004).

Em 1993, deflagrou-se um período de crise do SCA ao se constatar a falta de preparo dos trabalhadores associados na administração das CPAs. No mesmo ano, foi criado o Curso Técnico em Administração de Cooperativas (TAC), visando capacitar os dirigentes das cooperativas para a gestão dos empreendimentos. Em 1995, foi criado o Instituto Técnico de Capacitação e Pesquisa da Reforma Agrária (ITERRA), em Veranópolis-RS. Sua finalidade era assumir o curso TAC e o Magistério, centralizando a formação de técnicos e professores para atuarem nos assentamentos. Desde então, diversos cursos de capacitação e formação para o trabalho associado foram implantados pelo MST, em parceria com instituições nacionais e internacionais. Atualmente, o MST tem parceria com dezenas de 
Revista Tecnologia e Sociedade, Curitiba, v. 11, n. 22, 2015

Edição Especial XII Encontro Nacional de Engenharia e Desenvolvimento Social

ISSN (versão online): 1984-3526

ISSN (versão impressa): 1809-0044

universidades e possui cerca de quinze centros de formação em diversas regiões do país.

Essa experiência do início da década de 1990 foi fundamental para a elaboração, no Seminário da CONCRAB em junho de 1996, de diretrizes estratégicas (complementadas posteriormente) que deveriam orientar a atuação das CPAs, tendo destaque questões como a gestão coletiva do trabalho, gestão das relações interpessoais e a inserção no mercado. Entre as principais diretrizes estão: priorizar a inserção no mercado local e regional; buscar a diferenciação de produto: uso da marca MST (padronizar), preços menores ou mercados especiais (orgânicos; exportação); promover a diversificação da linha de produção; implantar a agroindustrialização, resultando em maior agregação de valor; fortalecer relações de intercooperação: MST, Anteag (Associação dos Trabalhadores de Empreendimentos Autogestionários), Confederação Nacional dos Metalúrgicos (CNM), Unitrabalho. ${ }^{8}$ De uma forma ou de outra, essas diretrizes ainda mantém-se hoje como orientadoras das práticas produtivas do movimento, cada vez mais atrelando-se a políticas públicas de apoio à agricultura familiar, como o Programa de Aquisição de Alimento (PAA) e do Programa Nacional de Aquisição Escolar (PNAE).

\section{A IMPORTÂNCIA DA AUTOGESTÃO NO INTERIOR DAS CPAS}

Desde os anos 1990, já se observava, nas cooperativas de produção agropecuária do MST, a preocupação em se garantir a autogestão, avançando na consciência da necessidade de se organizar coletivamente e não trabalhar individualmente. O movimento trabalha em uma perspectiva em que a terra das famílias é coletivizada, isto é, não há um limite ou cerca demarcando o que é de um ou de outro, embora essa prática nem sempre seja permitida em função dos trâmites legais para os assentamentos. Há casos, inclusive, onde a terra é titulada em nome da CPA. Quando uma família se desliga da CPA, recebe o seu lote em alguma parte da área. O capital da CPA é gerido coletivamente e participam do processo produtivo

\footnotetext{
${ }^{8}$ O objetivo maior da CNM é consolidar o movimento municipalista, fortalecer a autonomia dos Municípios a partir de iniciativas políticas e técnicas que visem à excelência na gestão e à qualidade de vida da população.A Anteag desenvolve e assessora projetos de autogestão a partir da viabilidade do negócio e da perspectiva dos próprios trabalhadores, buscando recuperar e manter o trabalho e renda, envolvendo a vontade e a inteligência coletiva.A Unitrabalho é uma rede nacional de universidades que apoia os trabalhadores na luta por melhores condições de vida e trabalho, com projetos de ensino, pesquisa e extensão, integrando o conhecimento acadêmico ao saber elaborado na prática social.
} 
Revista Tecnologia e Sociedade, Curitiba, v. 11, n. 22, 2015

Edição Especial XII Encontro Nacional de Engenharia e Desenvolvimento Social

ISSN (versão online): 1984-3526

ISSN (versão impressa): 1809-0044

todos os trabalhadores associados que têm no mínimo 16 anos, independente do sexo. A organização coletiva do trabalho autogestionário ocorre a partir dos setores de produção (agricultura, fruticultura, avicultura, suinocultura, bovinocultura, agroindústria e outros) e de serviços (secretaria, máquinas, comercialização, construções, refeitório, escola, ciranda).

A remuneração dos trabalhadores, em geral, se dá pela participação de cada sócio no trabalho, tanto produtivo como nas áreas de serviços. As atividades de serviços são remuneradas pela média dos setores de produção. Adota-se o princípio de "cada qual segundo o seu trabalho" e a contabilização do trabalho se dá pelas horas trabalhadas. Em algumas CPAs, já se discutia desde o final dos anos 90, o processo de implantação do controle por horas trabalhadas com adicional por produtividade aos trabalhadores mais produtivos para algumas atividades de trabalho. Em outras, a alternativa encontrada foi o estabelecimento de índices adicionais sobre o valor da hora trabalhada para algumas atividades de trabalho mais penosas, insalubres, sujeitas a causar doenças profissionais.

Em cada CPA, normalmente há um planejamento anual de safra, que serve de base para os planejamentos quinzenais das atividades dimensionando-se a necessidade de trabalho, tempo de trabalho, quantidade de trabalhadores, equipamentos e insumos necessários para as atividades do período. Quando necessário, há redimensionamentos do contingente de trabalhadores em setores, principalmente em períodos de colheita, onde a coordenação de cada setor discute as demandas por trabalho.

Apesar dessa trajetória, não é incomum haver experiências que não logram tornarse viáveis. Nos anos 90, foram construídas diversas agroindústrias do tipo "elefante branco", a exemplo do Pontal do Paranapanema (SP) e Marabá (PA), que denotaram a complexidade de se fazer trabalhadores camponeses se apropriarem de técnicas de produção, de gestão administrativa, comercial e financeira. Essas experiências contribuíram para embasar as demandas que o MST já apresentava, desde os anos 90, por educação do campo, assistência técnica, linhas de apoio e financiamento para a agroindustrialização, entre outras, em assentamentos de reforma agrária. 
Revista Tecnologia e Sociedade, Curitiba, v. 11, n. 22, 2015

Edição Especial XII Encontro Nacional de Engenharia e Desenvolvimento Social

ISSN (versão online): 1984-3526

ISSN (versão impressa): 1809-0044

UMA CONTRIBUIÇÃO AO DEBATE SOBRE CADEIAS PRODUTIVAS: SOLIDÁRIAS OU TRADICIONAIS?

$\mathrm{Na}$ busca pela sobrevivência, os empreendimentos solidários se veem obrigados a entrarem no mercado competitivo capitalista, que funciona na lógica do "para um ganhar, outro tem que perder". Nas relações estabelecidas nas cadeias produtivas, cada empreendimento busca maximizar seus benefícios, mesmo que isso signifique prejuízos a parceiros de longa data. No entanto, pode-se partir do pressuposto de que, nos procedimentos de trocas, as relações podem ter uma soma positiva, onde ambas as partes podem ganhar. Não se trata de tirar de um para dar a outro, mas de se estabelecer um sistema de relações econômicas e sociais que permitam ganhos a ambos. Os empreendimentos econômicos solidários, em função dos elementos do seu funcionamento interno, são propensos a praticarem esse outro tipo de relação de troca. Entretanto, destaca-se uma questão: como passar de uma economia popular onde há empreendimentos solidários relativamente isolados, praticando solidarismo apenas nas suas relações internas, para um solidarismo horizontal onde se possa criar e desenvolver um conjunto de práticas que interrelacionam essas iniciativas ao longo da cadeia produtiva?

Ir além da economia popular pressupõe pensar que o desenvolvimento autossustentável das comunidades pode significar, inicialmente, buscar planejar a integração de cada cadeia produtiva solidária, o que é estratégico para aumentar seu impacto no desenvolvimento local, endógeno e comunitário (MANCE, 2003). Para isso, é fundamental que ocorra um processo de mobilização do campo político e do campo econômico, criando oportunidades de trabalho e renda, superando gradativamente as dificuldades para melhoria nas condições e relações de trabalho.

Mance (2003, p. 26-27) defende que há um processo de formação de redes de economia solidária que integram organizações solidárias de crédito, produção, consumo, comércio e serviços, as quais passam a analisar as melhores estratégias de expansão, chegando algumas a sinalizar sobre a necessidade da remontagem de cadeias produtivas nas quais estão inseridas. "A ideia básica dessa remontagem consiste em substituir fornecedores de insumos que operam sob a lógica do capital por fornecedores que operam sob a lógica da economia solidária." (ibidem) O objetivo é alcançar a sustentabilidade social, econômica e ambiental. De fato, já 
Revista Tecnologia e Sociedade, Curitiba, v. 11, n. 22, 2015

Edição Especial XII Encontro Nacional de Engenharia e Desenvolvimento Social

ISSN (versão online): 1984-3526

ISSN (versão impressa): 1809-0044

encontramos na realidade brasileira algumas experiências que vão nesta direção apresentadas em Eid et al. (2006), Metello (2007), Rutkowski (2008), e Henriques et al. (2013).

Se a estratégia fosse priorizar o mercado externo, isso levaria, na maioria das vezes, a integrar os empreendimentos solidários em cadeias produtivas controladas por grupos econômicos oligopolistas, geralmente transnacionais. Ao coordenarem estas cadeias, os grupos oligopolistas passam a determinar a dinâmica do processo e o controle social, estabelecendo o ritmo da acumulação de capital. Pode-se, nesse contexto, pensar na reprodução dos processos históricos de integração entre diferentes produtores, muito comuns nas relações campesinato-empresário rural. No entanto, deve-se reconhecer também que as condições objetivas e subjetivas dificultam ou até impedem que empreendimentos solidários se organizem em todos os elos de cadeias produtivas estratégicas visando o desenvolvimento local, sob o controle social dos trabalhadores. O não aceite de parcerias com o pequeno empresário local pode significar o abandono de oportunidades de geração de trabalho e renda.

É importante que as cadeias produtivas sejam entendidas enquanto Cadeias de Produção, Cadeias de Valor Econômico, mas também enquanto Cadeias de Poder. E é justamente na percepção das cadeias produtivas como ambientes em que as relações de poder são estabelecidas que a compreensão de sua dinâmica torna-se fundamental para que os trabalhadores associados possam transitar no interior das cadeias produtivas em que estão atuando. No processo de organização de cadeias produtivas solidárias não basta a conquista de melhoria na qualidade de vida no curto prazo, também deve ser observada e corrigida a ocorrência de desvios de princípios.

\section{OS CASOS DA COOPERUNIAO E DA COPAVI}

Nesta seção, apresentamos dois casos que tiveram grande relevância na experimentação da prática da agroindustrialização em assentamentos da reforma agrária. Ambos, Cooperaunião e Copavi, tiveram seus pilares consolidados ao longo dos anos 1990 . 
Revista Tecnologia e Sociedade, Curitiba, v. 11, n. 22, 2015

Edição Especial XII Encontro Nacional de Engenharia e Desenvolvimento Social

ISSN (versão online): 1984-3526

ISSN (versão impressa): 1809-0044

\section{A COOPERUNIÃO}

Fundada em 1990, a Cooperativa de Produção Agropecuária União do Oeste (Cooperunião) faz parte do assentamento Conquista na Fronteira e está sediada no município de Dionísio Cerqueira, estado de Santa Catarina, considerado um porto seco por fazer uma tri-fronteira com as cidades de Barracão, no estado do Paraná, e Bernardo de Irigoyen, na Argentina. A história do assentamento remete à história do MST no estado de Santa Catarina.

As primeiras ocupações de terra no estado ocorreram em 1985, nos municípios de São Miguel do Oeste e em Abelardo Luz, no oeste de Santa Catarina, envolvendo mais de 1600 famílias. No dia 24 de junho de 1988, as famílias transferidas pelo INCRA através do MST chegaram à área, trazendo uma trajetória conjunta e uma proposta de trabalho associado. Já o grupo egresso do município de Dionísio Cerqueira não tinha uma vivência coletiva e muitas famílias acabaram desistindo. Em seu lugar foram assentados grupos de famílias do município e do MST. Assim, o assentamento se consolidou em dois grupos coletivos, denominados à época de 'grupo 1', formado pelas famílias do município e 'grupo 2', formado por famílias do MST.

Em 1989, foi elaborado o regimento interno, com as normas de funcionamento do assentamento e delineamento dos seus objetivos principais, dentre estes os voltados para a produção: a) Produção para a alimentação (curto prazo), voltada para produção de gêneros alimentícios necessários para a alimentação das famílias, buscando tirar da terra o seu sustento; b) Produção para a comercialização (médio prazo), com foco na alimentação das famílias e comercialização in natura do excedente; c) Produção e industrialização (longo prazo), que vislumbrava a industrialização da produção primária, agregando mais valor à produção, resultando em melhores condições econômicas para os assentados.

Em outubro de 1990, 41 trabalhadores do 'grupo 2', pertencentes ao MST, fundaram a Cooperativa de Produção Agropecuária União do Oeste (Cooperunião), com o objetivo de ser uma CPA voltada para fomentar a produção e facilitar as compras, vendas, o acesso ao crédito e a aquisição de maquinários. Após um curso de formação direcionado para todo o assentamento, foi articulada a entrada de 
Revista Tecnologia e Sociedade, Curitiba, v. 11, n. 22, 2015

Edição Especial XII Encontro Nacional de Engenharia e Desenvolvimento Social

ISSN (versão online): 1984-3526

ISSN (versão impressa): 1809-0044

assentados do 'grupo 1' na cooperativa, o que veio a se concretizar em 1992. Em 1994, houve a unificação dos grupos no tocante à coletivização das terras, dos meios de produção e do processo de trabalho na cooperativa. Assim, todas as famílias do 'grupo 1' passaram a integrar o quadro social da cooperativa, tendo os mesmos direitos e deveres dos sócios fundadores.

Em 1996, definiram-se os setores estratégicos, que receberiam os maiores investimentos para futuro retorno econômico: produção e industrialização do frango de corte, produção de leite in natura, produção de peixe, produção de erva mate in natura, produção de milho, soja e trigo, além da alimentação para a auto sustentação.

No ano de 2004, o empreendimento conseguiu um financiamento para a construção de 52 casas de alvenaria, melhorando as condições de moradia dos cooperados. A cooperativa possui uma política de empréstimo financeiro para os associados por um ano sem incidência de juros e debitado na conta anual de distribuição de sobras. Esses recursos são direcionados para realização de exames médicos, consultas a especialistas, compra de medicamentos, entre outras necessidades.

Com a melhoria da infraestrutura social e produtiva, em 1997 a Cooperunião adentrou na agroindustrialização, com a construção do abatedouro de aves com capacidade de abate de 1000 aves/hora. No entanto, nos primeiros anos, a cooperativa operou durante com menos de $30 \%$ de sua capacidade instalada, o a levou a oferecer, em 2008, a prestação do serviço de abate para produtores da região. Em 2011, o abatedouro operava com aproximadamente $70 \%$ de sua capacidade instalada.

Em um dia de produção, o abatedouro recebe aves e realiza o abate durante 5 horas, com maior número de horas destinadas à prestação de serviço para terceiros. Durante outras três horas são realizadas a limpeza do abatedouro e a manutenção preventiva dos equipamentos. Na figura 1, pode-se observar a evolução da produção no setor de 2006 a 2010, tanto no abate da produção própria quanto na prestação de serviço:

A Cooperunião utiliza a marca Terra Viva para comercializar o frango de corte próprio. Com o aumento da atividade de prestação de serviços, ocorreu uma diminuição na produção e industrialização do frango de corte próprio e aumento na 
Revista Tecnologia e Sociedade, Curitiba, v. 11, n. 22, 2015

Edição Especial XII Encontro Nacional de Engenharia e Desenvolvimento Social

ISSN (versão online): 1984-3526

ISSN (versão impressa): 1809-0044

prestação de serviços, em razão da elevação no custo de manutenção da produção própria em comparação à prestação de serviços para terceiros.

Em 2010, a cooperativa era formada por 48 famílias, totalizando 154 sócios entre homens, mulheres e jovens. O faturamento médio anual da cooperativa, de 2008 a 2010, esteve estacionado na faixa de $R \$ 2$ milhões, sendo que a redução dos preços pagos pela produção e seu elevado custo ano a ano reduziram a margem de ganho da cooperativa e consequentemente a distribuição de sobras aos trabalhadores associados. Toda a estrutura produtiva e social da cooperativa é arquitetada em um desenho organizacional que contempla os aspectos social e econômico da Cooperunião.

\section{A COPAVI}

A Cooperativa de Produção Agropecuária Vitória LTDA (Copavi), está localizada no Assentamento Santa Maria, município de Paranacity-PR, região noroeste do Paraná, a uma distância de $403 \mathrm{~km}$ da capital Curitiba. O assentamento Santa Maria foi criado mediante a desapropriação da Fazenda Santa Maria, em junho de 1988. Inicialmente, a área foi ocupada provisoriamente por um grupo de trabalhadores Sem Terra de Paranacity logo após ser desapropriada, e somente em 1993 as 25 famílias ligadas ao MST ocuparam a área para produzir de forma coletiva para sua subsistência. Algumas dessas famílias já ocupavam a terra há mais de dois anos e, mesmo sem contar com a posse legal dela, conquistaram o apoio e simpatia da população local para reivindicar sua posse definitiva. Nos primeiros seis meses de ocupação, as famílias dedicaram-se a trabalhar como boia-fria em propriedades da região, ao mesmo tempo em que discutiam sobre como seria a organização do assentamento, quais objetivos e princípios norteariam o seu funcionamento.

A fundação da Copavi, em 10 de julho de 1993, objetivou dar início ao desenvolvimento das atividades coletivas e angariar investimentos produtivos. A Copavi é vinculada à CONCRAB, por meio da Cooperativa Central de Reforma Agrária do Paraná - CCA-PR - e busca seguir as orientações do MST nas suas linhas políticas, princípios e símbolos definidos em âmbito nacional. Durante todo o período de resistência, foram realizadas várias reuniões entre os trabalhadores acampados, quando se discutiu sobre a melhor forma de utilização da terra e sobre 
Revista Tecnologia e Sociedade, Curitiba, v. 11, n. 22, 2015

Edição Especial XII Encontro Nacional de Engenharia e Desenvolvimento Social

ISSN (versão online): 1984-3526

ISSN (versão impressa): 1809-0044

a organização do trabalho. Em maio de 1994, o INCRA emitiu o título de propriedade da terra ocupada em nome da cooperativa, de maneira que a terra e os ativos constituídos fossem de propriedade da Copavi, impossibilitando seu fracionamento individual para alienação. A utilização dos recursos de maneira coletiva sob a forma de uma cooperativa se colocou como uma premissa para os trabalhadores e sua posterior adesão como sócios. Inicialmente, as 20 famílias que fundaram a cooperativa "[...] transformaram uma área pequena de 256 hectares com apenas a cultura de cana-de-açúcar (72\% da área), inabitada, em lugar de morada e de geração de renda" (MOURA, 2006, p.71).

Conforme relatado por Moura (2006), a partir de 1994, com a regularização do assentamento, a Copavi estava apta a acessar financiamentos do Programa de Crédito Especial para a Reforma Agrária (PROCERA). Em 1995, a cooperativa conseguiu um financiamento, pelo Procera, no valor de $R \$ 300$ mil que foi utilizado, centralmente, para fortalecer as seguintes atividades: horticultura; fruticultura; pecuária de leite; criação de aves; café adensado e processamento da cana-deaçúcar para produção de cachaça e rapadura.

As linhas de crédito do Procera permitiram que a Copavi desse início às atividades agroindustriais para maior agregação de valor à produção, impactando na organização do trabalho na cooperativa. Com esse aporte financeiro, a cooperativa adquiriu, a partir de 2000, considerável autonomia financeira, fazendo com que parte de suas atividades, de seus investimentos e mesmo da distribuição de sobras para os cooperados resultasse das receitas oriundas da comercialização de sua produção.

As atividades produtivas da cooperativa são concentradas em dois setores de produção que: leite e derivados, que produz leite, iogurte, queijo e doce de leite; e cana e derivados, produzindo cana in natura, açúcar mascavo, melado e cachaça. Em 2010, a Copavi teve uma receita de $\mathrm{R} \$ 842.801,68$, com cana e derivados sendo responsável por cerca de $52 \%$ da receita, leite e derivados, $31 \%$, panificados, $4 \%$, cachaça, 3\%, e outros produtos e serviços com cerca de 10\% (GONÇALVES, 2011).

O quadro de trabalhadores associados da cooperativa, em 2011, era composto por 53 cooperados, sendo 25 homens, 17 mulheres e 11 jovens, distribuídos pelos setores de produção. A cooperativa contava também com 19 empregados contratados como força de trabalho assalariada, atuando 
Revista Tecnologia e Sociedade, Curitiba, v. 11, n. 22, 2015

Edição Especial XII Encontro Nacional de Engenharia e Desenvolvimento Social

ISSN (versão online): 1984-3526

ISSN (versão impressa): 1809-0044

especificamente na atividade de corte de cana-de-açúcar no setor de cana e derivados.

\section{PROGRAMAS FEDERAIS PARA AGROINDUSTRIALIZAÇÃO}

Nesta seção, apresentamos as experiências de algumas políticas públicas de apoio à agroindustrialização que foram sendo desenvolvidas no âmbito federal nas últimas décadas. Esses programas são reflexo, por um lado, da agenda de luta apresentada pelos movimentos sociais rurais, e, por outro lado, dos aprendizados adquiridos com êxitos e fracassos das práticas de apoio ao agricultor familiar.

\section{PRONAF}

Para Schneider, Mattei e Cazella (2004), a elaboração e a constituição do Programa Nacional de Fortalecimento da Agricultura Familiar (Pronaf) são resultado das pressões do movimento sindical que ocorreram a partir do final da década de 1980. Como resposta, o governo federal instituiu um programa com a finalidade de prover crédito agrícola e apoio institucional aos pequenos produtores rurais. Esta nomenclatura fazia alusão aos agricultores familiares e aos pequenos empresários rurais reconhecidos como mini-produtores.

Em 1994, as reivindicações dos agricultores familiares em negociação com o governo Itamar Franco resultaram na criação do Programa de Valorização da Pequena Produção Rural (Provap), que operava com recursos do Banco Nacional do Desenvolvimento Econômico e Social (BNDES). Esse Programa é considerado o precursor da primeira e mais importante política diferenciada para o agricultor familiar. Sua reformulação, na concepção e área de abrangência, ocorre no mandato do presidente Fernando Henrique Cardoso, com a criação do Pronaf em 1996. Na sua concepção inicial, não previa o financiamento de atividades de agregação de valor. A inclusão de uma linha de atuação para a agroindústria ocorreu a partir dos debates sobre a importância da agroindústria como estratégia de fortalecimento dos pequenos produtores rurais. A criação do Pronaf Agroindústria ocorre somente em 1999, pelo Ministério da Agricultura.

As dificuldades na normatização do Pronaf Agroindústria e a transferência do Pronaf do Ministério da Agricultura para o Ministério do Desenvolvimento Agrário, 
Revista Tecnologia e Sociedade, Curitiba, v. 11, n. 22, 2015

Edição Especial XII Encontro Nacional de Engenharia e Desenvolvimento Social

ISSN (versão online): 1984-3526

ISSN (versão impressa): 1809-0044

fizeram com que o programa fosse descaracterizado, perdendo muito da estrutura e filosofia com que havia sido pensado, deixando, por exemplo, de garantir recurso a fundo perdido para a área de infraestrutura de agroindústrias ou de prever apoio técnico para as agroindústrias (MIOR, 2005).

\section{AGREGAR x PRONAF AGROINDÚSTRIA}

Mior (2005) descreve também o desinteresse por parte do agente financeiro para operacionalizar o Pronaf Agroindústria, o que acarretou o direcionamento dos projetos de agregação de valor para a Linha de Crédito de Investimento para Agregação de Renda à Atividade Rural (Agregar). A linha AGREGAR aceitava propostas individuais e operava prioritariamente com agroindústrias já estabelecidas, sendo que, as condições de financiamento não eram animadoras para as novas agroindústrias. Havia uma lógica de exigência de garantias reais que dificultava o acesso, o serviço governamental de Assistência Técnica e Extensão Rural (ATER) em áreas de assentamento era deficitária e não havia o interesse por parte dos bancos para financiar pequenos empreendimentos da reforma agrária. É importante frisar que $80 \%$ dos investimentos desta linha de crédito foram implementadas no na região centro-sul do país.

A análise econômica para viabilidade do empreendimento na linha Agregar deveria ser feita na propriedade e não apenas na agroindústria, como foi proposto pelo Pronaf Agroindústria. Além disso, era financiado o empreendimento de forma individual e não mais coletivo. Para Mior (2005), essas eram as principais diferenças entre o Pronaf Agroindústria e a linha Agregar. Como sequela dessa forma de financiar, ocorreu a exclusão dos agricultores menos capitalizados do processo, uma vez que ao financiar as agroindústrias isoladas se extinguiu a concepção de trabalho em rede. Atualmente, o Pronaf Agroindústria abrange tanto agricultores individuais, como as organizações sociais em forma de cooperativas.

Em 2015, as ações do Pronaf Agroindústria estão com um limite de financiamento de $R \$ 150$ mil para pessoa física; $R \$ 300$ mil por Empreendimento Familiar Rural; R\$35 milhões por Cooperativa/Associação (respeitando o limite de $\mathrm{R} \$ 45$ mil por associado/cooperado relacionado na DAP, Declaração de Aptidão ao Pronaf, emitida para a agroindústria); e até $30 \%$ do valor do financiamento para 
Revista Tecnologia e Sociedade, Curitiba, v. 11, n. 22, 2015

Edição Especial XII Encontro Nacional de Engenharia e Desenvolvimento Social

ISSN (versão online): 1984-3526

ISSN (versão impressa): 1809-0044

beneficiamento, processamento ou comercialização oriunda da produção agropecuária. Além disso, quinze por cento (15\%) do valor do financiamento de cada unidade agroindustrial pode ser aplicado para a unidade central de apoio gerencial no caso de projetos de agroindústrias em rede ou, quando for o caso de agroindústrias isoladas, para pagamento de serviços como contabilidade, desenvolvimento de produtos, controle de qualidade, assistência técnica gerencial e financeira (BNDES, 2015).

A partir do governo Lula (2003-2010), com a redefinição das competências do Ministério do Desenvolvimento Agrário, houve o resgate e fortalecimento das ações de ATER e dos programas para as áreas de assentamentos, instituídas por meio da Política Nacional de Assistência Técnica e Extensão Rural (Pnater) e do Programa Nacional de Assistência Técnica e Extensão Rural para a Agricultura Familiar e Reforma Agrária (Pronater).

Dessa forma, em 2015, atrelados a Pnater e ao Pronater, instituídos em 2003, estão as ações do Programa Nacional de Fortalecimento da Agricultura Familiar (Pronaf) instituído em 1995, assim como, o referencial do Programa de Assessoria Técnica, Social e Ambiental à Reforma Agrária (Ates) do INCRA, de 2008 (MDA, 2007). Nesse manual consta, por exemplo, o modelo de um Documento de Caracterização Regional do Programa de Ates onde o INCRA deve organizar as informações das demandas existentes nas áreas de assentamento e estabelece os eixos de trabalho da assessoria técnica (idem, 2008, p. 35). Dentre as diretrizes a serem seguidas pela Ates consta a "Geração de Renda e Agregação de Valor" (idem, 2008, p. 67). Dessa forma, dentre as temáticas trabalhadas pelo serviço de ATES deverá haver uma que trate de agroindústria familiar com elaboração de projetos para a ação Terra Sol e para o Pronaf Agroindústria.

\section{PROGRAMA TERRA SOL}

O Programa Terra Sol foi criado em 2004 como parte do Plano Nacional de Reforma Agrária (II PNRA) e do Plano Plurianual (PPA). Executado a partir de 2006 com projetos de ação de fomento à agroindustrialização, à comercialização e à atividades pluriativas solidárias, tem como objetivo o "[...] aumento de renda dos assentamentos da reforma agrária por meio de atividades socioeconômicas 
Revista Tecnologia e Sociedade, Curitiba, v. 11, n. 22, 2015

Edição Especial XII Encontro Nacional de Engenharia e Desenvolvimento Social

ISSN (versão online): 1984-3526

ISSN (versão impressa): 1809-0044

sustentáveis, valorizando as características regionais, experiências e potencialidades locais, com ênfase na agroecologia". ${ }^{9}$ Foi concebido para financiar agroindústrias via convenio com estados e municípios ou por execução direta do próprio INCRA. No entanto, pelo nível de exigência da articulação entre as diversas instituições em nível municipal, estadual, e federal encontra dificuldades para ser operacionalizado na maioria dos estados.

Atualmente, a seleção de projetos é feita via chamadas públicas e os recursos orçamentários disponibilizados para a maioria das seleções públicas de projetos são de responsabilidade do INCRA. O INCRA, também nesta modalidade, promove chamadas exclusivas para mulheres produtoras rurais. Duas são as linhas de trabalho: Linha Apoio, com ações de: (i) Implantação e recuperação de agroindústrias; (ii) Aquisição de equipamentos para agroindústrias; (iii) Capacitação dos beneficiários para a atividade agroindustrial; (iv) Comercialização, divulgação e venda dos produtos da reforma agrária; (v) Capacitação dos beneficiários em gestão administrativa e comercialização; (vi) Atividades pluriativas: turismo rural e ecoturismo; (vii) Restaurantes rurais; e (viii) Artesanato. E a Linha Agroecologia, com foco em: (i) fomentar estudos e projetos inseridos em uma estratégia de transição agroecológica; (ii) o beneficiamento e comercialização de produtos agroecológicos; (iii) apoiar a implementação, em caráter demonstrativo, de iniciativas com bases agroecológicas.

\section{PROGRAMA TERRA FORTE}

O Programa Terra Forte, instituído em 2013, tem como público beneficiário as famílias dos Projetos de Assentamento (PA) criados ou reconhecidos pelo INCRA, e organizadas em cooperativas ou associações de produção e/ou de comercialização. Seu objetivo é fomentar a implantação e/ou modernização de empreendimentos coletivos agroindustriais em Projetos de Assentamento da Reforma Agrária, criados ou reconhecidos pelo Incra, em todo o território nacional. ${ }^{10}$

O Terra Forte funciona a partir de um fluxo de de processos que propõe uma continuidade na estruturação dos projetos, realizando, primeira uma seleção de préprojetos que são inseridas na carteira de projetos do Incra. Os pré-projetos

\footnotetext{
${ }^{9}$ Disponível em: http://www.incra.gov.br/programa_terra_sol

${ }^{10}$ Disponível em: http://www.incra.gov.br/terraforteprograma
} 
Revista Tecnologia e Sociedade, Curitiba, v. 11, n. 22, 2015

Edição Especial XII Encontro Nacional de Engenharia e Desenvolvimento Social

ISSN (versão online): 1984-3526

ISSN (versão impressa): 1809-0044

aprovados pelo Incra devem ser detalhados minuciosamente para a seleção de projetos que serão financiados pelo Terra Forte. Vale destacar que há uma grande exigência de detalhamento dessa chamada pública, o que representa uma das principais dificuldades para que as associações e cooperativas dos assentamentos consigam ter seus projetos de agroindustrialização aprovados. Os itens de detalhamento dos candidatos são: Apresentação da proponente; Aspectos Sociais; Aspectos Tecnológicos, Organizacionais e de Infraestrutura; Aspectos Mercadológicos; Aspectos Ambientais; Aspectos Econômico-Financeiros; Documentação; Modelos de Declarações.

As propostas de apoio devem ser confeccionadas pelas entidades a serem atendidas, o que requer um nível de conhecimento que muitas vezes é deficitário nas organizações familiares, principalmente das regiões Norte e Nordeste. Assim, é necessária uma boa articulação com entidades de todos os setores da sociedade (ONGs, universidade, políticos, etc.), para que sejam auxiliados na formulação das propostas. Na somatória do valor do montante requerido como apoio deve constar os recursos reembolsável e não reembolsável, sendo que o valor máximo em recursos não reembolsáveis é de $\mathrm{R} \$ 10$ milhões, que deve representar, no máximo, $90 \%$ do orçamento total do projeto, para empreendimentos localizados nas regiões Norte e Nordeste e em municípios do Semiárido inseridos no estado de Minas Gerais, ou $80 \%$ do orçamento total, para empreendimentos localizados nas regiões Centro-Oeste, Sul e demais municípios da região Sudeste. ${ }^{11}$

Aprendendo de experiências anteriores, o Programa Terra Forte vem acompanhado de uma proposta de formação contínua dos trabalhadores associados e de técnicos que possam apoiar a elaboração e acompanhamento dos projetos de agroindústrias. Um dos pontos nodais da arquitetura do projeto remete à capacitação dos cooperados para a gestão dos empreendimentos a partir de uma intensa dotação técnica-instrumental advinda da implantação das agroindústrias, bem como do manejo de ferramentas de gestão para a produção e o escoamento no mercado.

Dentre as diversas etapas de formação/capacitação encontram-se as oficinas sobre Cadeias Produtivas. Estas oficinas, ministradas por professores e

\footnotetext{
${ }^{11}$ Disponível em:

http://www.incra.gov.br/media/servicos/editais/2013/REGULAMENTO\%20TERRA\%20FORTE.pdf
} 
Revista Tecnologia e Sociedade, Curitiba, v. 11, n. 22, 2015

Edição Especial XII Encontro Nacional de Engenharia e Desenvolvimento Social

ISSN (versão online): 1984-3526

ISSN (versão impressa): 1809-0044

pesquisadores ligados à temática da gestão da produção, mas que se debruçam sobre o estudo da trajetória das cooperativas populares, tem por objetivo emular a apropriação dos conceitos relativos ao estado da arte sobre as cadeias produtivas, mas também aproximar o léxico das experiências concretas dos trabalhadores associados.

A grande exigência de detalhamento dos projetos para o edital, que muitos consideram inadequado para o contexto que pretende apoiar, pode ser retratada nos números da primeira seleção que está em andamento desde 2013. De centenas de projetos enviados pouco mais de 100 foram aprovados para a carteira do Incra. Seus proponentes fizeram o detalhamento das propostas e apenas 32 foram selecionados para a carteira de projetos do Terra Forte. Estes ainda passarão por uma avaliação mais profunda para poderem ser financiados, como destaca a notícia do próprio Incra, onde fora divulgados os projetos aprovados: "A seleção para a carteira do Terra Forte é a segunda etapa do processo, e não representa nenhuma obrigatoriedade de apoio ao projeto. Após selecionados, os projetos da carteira passarão por uma qualificação. A indicação para investimento só é feita se ficar comprovada a viabilidade do empreendimento". ${ }^{12}$ Vale destacar que entre os 11 projetos selecionados para receber um volume maior de recursos (mais de $R \$ 3$ milhões), sete são da região sul do país ${ }^{13}$, o que é um reflexo a diferença de infraestrutura e organização que há entre as regiões do país e que não pode, ou não deve, ser ignorada.

\section{A EXPERIÊNCIA DE ASSESSORIA À COOPATERRA}

Apresentamos, nesta seção, a experiência de trabalho que vem sendo desenvolvido pelo Núcleo de Solidariedade Técnica da Universidade Federal do Rio Janeiro (Soltec/UFRJ) com a Cooperativa de Produção Agroecológica Terra Fértil (Coopaterra), uma organização produtiva que busca articular a produção de quatro assentamentos e uma comunidade do MST e que hoje está se estruturando para conseguir implantar uma agroindústria. Com a análise deste caso pretendemos ilustrar, por um lado, a importância de uma política pública sólida de viabilização de

\footnotetext{
12 http://www.incra.gov.br/noticias/incra-divulga-rela\%C3\%A7\%C3\%A3o-final-de-projetos-selecionados-peloprograma-terra-forte

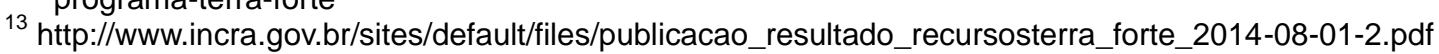


Revista Tecnologia e Sociedade, Curitiba, v. 11, n. 22, 2015

Edição Especial XII Encontro Nacional de Engenharia e Desenvolvimento Social

ISSN (versão online): 1984-3526

ISSN (versão impressa): 1809-0044

unidades de processamento no assentamentos da reforma agrária, por outro, os desafios e dificuldades enfrentados para a organização e, principalmente, o atendimento das exigências colocadas pelas políticas governamentais, particularmente pelo programa Terra Forte.

\section{A CRIAÇÃO DA COOPATERRA}

A história do assentamento onde hoje se localiza a Coopaterra começa em 1999, quando surge o acampamento Terra Prometida na fazenda de Santana, município de Miguel Pereira/RJ. O acampamento era formado por 153 famílias, de origem urbana e rural, organizadas pelo Movimento dos Trabalhadores Rurais Sem Terra (MST). A esperança de desapropriação era tão certa que deu origem ao nome do acampamento.

Não conseguindo a desapropriação dessa terra, em 2000, os trabalhadores partiram para a ocupação da nova região que se localizava as margens da Baía de Sepetiba, em Santa Cruz, Zona Oeste do município do Rio de Janeiro. Após nova derrota por lentidão e falta de vontade política dos órgãos governamentais, em 2006, os trabalhadores mudam-se novamente para um novo acampamento em Nova Iguaçu. Depois de mais de um ano de cobrança ao ITERJ, houve um processo de desapropriação para fins sociais das fazendas Sempre Verde e Paraíso nos município de Nova Iguaçu e Duque de Caxias, assentando cerca de 50 famílias.

Apesar de assentados, a carência de infraestrutura do assentamento prejudica muito a produção agrícola e sua venda. As principais dificuldades encontradas são a falta de drenagem, estradas precárias e instabilidade da energia elétrica. Nesse árduo contexto, começa uma mobilização para aumentar a cooperação e minimizar as dificuldades. A Coopaterra surge, então, a partir da realização de mutirões de produção, ainda como um grupo não formalizado. Os mutirões eram organizados por assentados que buscavam, de forma participativa, discutir a viabilidade da produção agroecológica e sustentável nos assentamentos, visando a melhoria da qualidade de vida dos assentados e suas famílias, através da geração de renda pela produção e comercialização de alimentos saudáveis. Essa mobilização levou à articulação com outras comunidades agrícolas ligadas ao MST que estão em municípios próximos à capital. Atualmente, a Coopaterra é composta 
Revista Tecnologia e Sociedade, Curitiba, v. 11, n. 22, 2015

Edição Especial XII Encontro Nacional de Engenharia e Desenvolvimento Social

ISSN (versão online): 1984-3526

ISSN (versão impressa): 1809-0044

por famílias pertencentes a quatro assentamentos e um acampamento, localizados nas regiões Baixada e Sul do Rio de Janeiro, atingindo cerca de 80 cooperados entre homens, mulheres e jovens.

Os anos 2008 e 2009 são o marco inicial de um processo mais institucional da Coopaterra, com implantação de agrofloresta nos lotes de assentados e a diversificação da produção. As atividades de cada lote eram autogestionadas, possibilitando a cooperação entre as famílias que trocavam trabalho, equipamentos e insumos para a produção. O planejamento era realizado através da identificação de demandas e da reflexão e discussão coletiva das estratégias mais adequadas para responder às mesmas. Desta forma, escolhiam-se, por exemplo, as áreas para plantio, preparo e cultivo e se tomavam as decisões sobre a colheita, cultura e comercialização. Todos os participantes da cooperativa, lideranças e camponeses mais ligados à produção, eram convocados para assembleias para discutir e tomar as decisões, garantindo assim a construção coletiva do projeto.

\section{A ESTRUTURAÇÃO DA COMERCIALIZAÇÃO E DO BENEFICIAMENTO}

Ainda informal, o grupo participou, em 2010, da $1^{\text {a }}$ Feira Estadual da Reforma Agrária, organizada por grupos de cooperativas de assentados da Reforma Agrária do Rio de Janeiro, onde recebeu o convite para participar da Rede Ecológica do Rio de Janeiro, que são grupos de consumidores que realizam compras coletivas diretamente de pequenos produtores agroecológicos. O fornecimento para a Rede Ecológica foi o ponto de partida para uma série de transformações na forma de produzir, pois exigia uma organização mais afinada para o fornecimento quinzenal de diversos produtos. Era preciso melhorar o nível de organização e diversificar a produção, bem como sistematizar e agregar novos camponeses para atender à demanda.

Depois desta parceria, surgiram oportunidades para participar de outros espaços de comercialização, como as feiras livres em Nova Iguaçu e Duque de Caxias e venda de cestas da Reforma Agrária. Esses espaços promoveram novos avanços na organização dos camponeses, pela necessidade de ampliação da produção para atender o mercado em diferentes momentos de entrega e venda. $A$ 
Revista Tecnologia e Sociedade, Curitiba, v. 11, n. 22, 2015

Edição Especial XII Encontro Nacional de Engenharia e Desenvolvimento Social

ISSN (versão online): 1984-3526

ISSN (versão impressa): 1809-0044

expansão na venda foi exigindo uma maior organização, o que levou à formalização da cooperativa em 2012.

A Coopaterra vem desenvolvendo ações que buscam viabilizar uma melhor organização da produção agroecológica. Através de recursos próprios, a Cooperativa adquiriu um caminhão para o transporte da produção, e um freezer vertical e uma geladeira para acondicionar o material antes da entrega. Também foram adquiridos alguns equipamentos para apoiar a venda e beneficiamento, como balança digital de precisão, embaladora e seladora a vácuo, desidratado para frutas, legumes e plantas medicinais, assim como as embalagens para atender a produção a vácuo e os desidratados.

Esse maquinário básico permite que a cooperativa venda alguns produtos beneficiados: polpas, aipim branco ou amarelo descascado, aipim branco ou amarelo ralado, goma para tapioca, jaca dura ou mole desgomada, cana descascada em palitos, bolos, doces, queijo, biscoito, salgados. No entanto, há necessidade de avançar para produtos que possam ter maior prazo de validade, para não ficar sujeito às variações do mercado e refém de fenômenos climáticos, e que os possibilite também acessar outros mercados.

\section{O SONHO DA AGROINDÚSTRIA E AATUAÇÃO DO SOLTEC/UFRJ}

Em função desse cenário, a cooperativa vem construindo a estratégia de implantação de uma agroindústria, com o intuito de fomentar a produção coletiva no assentamento com maior qualidade, gerar maior renda, principalmente para os jovens com o beneficiamento dos alimentos, aumentar o tempo de armazenamento e produzir bens mais atraentes para o consumidor. A principal política pública para o financiamento de agroindústrias em assentamentos da reforma agrária, atualmente, é o edital Terra Forte. Entretanto, há que se traçar um longo caminho de institucionalização e organização para se chegar lá, e foi para apoiar essa caminhada que o Núcleo de Solidariedade Técnica (Soltec/UFRJ) ${ }^{14}$ passou a dialogar com a Coopaterra. Ao longo de 2014, consolidou-se o diálogo institucional e

14 "O Núcleo de Solidariedade Técnica (SOLTEC/UFRJ) é um programa interdisciplinar de extensão, pesquisa e formação, que desenvolve projetos em rede com abordagem territorial e participativa, nos campos da Tecnologia Social e da Economia Solidária, visando à construção de políticas públicas para a equidade social e o equilíbrio ambiental", extraído de www.soltec.ufri.br, em 28 de junho de 2015. 
Revista Tecnologia e Sociedade, Curitiba, v. 11, n. 22, 2015

Edição Especial XII Encontro Nacional de Engenharia e Desenvolvimento Social

ISSN (versão online): 1984-3526

ISSN (versão impressa): 1809-0044

uma série de conversas e atividades para um maior conhecimento da realidade da cooperativa por parte do grupo universitário.

A partir da estratégia metodológica da pesquisa-ação (Thiollent, 2011), o Soltec/UFRJ começou a conhecer a realidade e construiu, junto com a coordenação da cooperativa, uma proposta de trabalho que tem como objetivo central estruturar a cooperativa. O plano de trabalho é dividido em quatro momentos: (a) planejamento das atividades; (b) Estudo de Viabilidade Técnica, Econômica, Social e Ambiental (Evtesa); (c) elaboração do plano do empreendimento; e (d) formação e assessoria.

Assim, o projeto começou com a realização de uma planejamento dialógico e participativo das atividades, que envolveu as coordenações, pesquisadores e técnicos da Coopaterra e do Soltec, e com a definição das equipes de trabalho, equipe de pesquisa e equipe de apoio, compostas por integrantes de ambos os grupos. Em março de 2015, iniciou-se o estudo de viabilidade, com a perspectiva de apresentar um relatório inicial em agosto do mesmo ano. O Evtesa pretende contribuir para um conhecimento mais amplo e profundo sobre a cooperativa, levando em conta não só a parte econômica mas também os aspectos socioambientais e técnicos. A metodologia utilizada é uma adaptação da proposta pela organização não-governamental Cooperação e Apoio a Projetos de Inspiração Alternativa para estudo de viabilidade econômica de empreendimentos associativos (CAPINA, 1998). ${ }^{15}$

$\mathrm{Na}$ fase seguinte, será elaborado um plano do empreendimento com a finalidade de construir coletivamente, com base no estudo de viabilidade, um plano estratégico do empreendimento que oriente as decisões de produção e comercialização em curto, médio e longo prazo. A fase final do projeto se dá com a formação e assessoria, através de um curso de extensão, que usará a metodologia da pedagogia da alternância.

\section{OS DESAFIOS E DIFICULDADES PARA O FINANCIAMENTO DE UMA AGROINDÚSTRIA NA COOPATERRA}

\footnotetext{
${ }^{15}$ No portal da organização, www.capina.org.br, estão disponíveis dois livros que podem servir de base para esse tipo de trabalho com empreendimentos solidários: "Puxando o fio da meada" e "Retomando o fio da meada.
} 
Revista Tecnologia e Sociedade, Curitiba, v. 11, n. 22, 2015

Edição Especial XII Encontro Nacional de Engenharia e Desenvolvimento Social

ISSN (versão online): 1984-3526

ISSN (versão impressa): 1809-0044

Em função de um longo e cansativo trabalho realizado nos últimos anos, a Coopaterra tem conseguido organizar-se cada vez mais para buscar atender às demandas do mercado e das políticas públicas. Podemos resumir, de forma simplificada, os desafios para o acesso à política de agroindustrialização dos assentamentos em três eixos: formalização, organização produtiva e elaboração do projeto.

A resolução de pendências de formalização da cooperativa foi um primeiro passo ao qual dedicou-se grande esforço. A primeira batalha foi para o reconhecimento de uma área produtiva rural no município de Duque de Caxias, cuja prefeitura ignora completamente as atividades de produção da agricultura familiar em seu território, o que pode ser comprovado pela ausência de políticas públicas municipais voltadas para esse setor e pelo fato de haver apenas uma subsecretaria direcionada à agricultura, dentro da Secretaria de Meio Ambiente.

Não obstante, o processo de formalização foi um passo fundamental para que a cooperativa conseguisse atingir um objetivo que é considerado, pelo cooperados, como uma etapa para obter a agroindústria: o acesso ao Programa Nacional de Alimentação Escolar (PNAE). ${ }^{16}$ O PNAE determina que no mínimo $30 \%$ dos recursos devem ser destinados à compra de produtos do agricultor familiar, havendo prioridade para os produtores vinculados à cooperativas e aos assentados da reforma agrária. Entretanto, para acessar o programa há a exigência do cadastro e de uma série de documentações que precisam ser apresentadas pela cooperativa. A Coopaterra cumpriu os requisitos básicos e está concorrendo para começar a fornecer alimentos para as escolas da região a partir do segundo semestre de 2015.

$O$ avanço de vendas a atacado na região e o acesso ao PNAE vão contribuir para estruturar o segundo eixo de desafios para a agroindústria que é a organização produtiva. Atualmente, a Coopaterra tem uma saída diária de um caminhão, que leva centralmente aipim in natura, para vender para mercados dos bairros próximos. Essa demanda têm exigido uma organização cotidiana do trabalho e da relação com os agricultores, que precisam estar afinados com a estratégia de vendas da cooperativa para que esta não deixe de atender aos pedidos de seus clientes. Essa dinâmica não era tão organizada quando o principal canal de venda eram feiras

\footnotetext{
${ }^{16}$ Detalhes podem ser vistos em http://www.fnde.gov.br/programas/alimentacao-escolar/alimentacao-escolarapresentacao. Acessado em 28 de junho de 2015.
} 
Revista Tecnologia e Sociedade, Curitiba, v. 11, n. 22, 2015

Edição Especial XII Encontro Nacional de Engenharia e Desenvolvimento Social

ISSN (versão online): 1984-3526

ISSN (versão impressa): 1809-0044

esporádicas. A exigência de um fornecimento diário tem sido um importante trunfo para a estruturação produtiva do empreendimento.

Com a aprovação do PNAE, a expectativa é que haja a demanda de entrega de caixas de aipim e abobrinha duas vezes por mês para no mínimo 25 escolas do município, mas podendo chegar a 92 unidades em seis municípios diferentes. Nesse cenário, será adicionado ao trabalho atual, a exigência de um planejamento sólido da produção que garanta a disponibilidade de produtos que devem ser entregues nas escolas. A organização de fornecimento dos alimentos pelos agricultores deverá não apenas ser tocada no cotidiano, mas planificada antecipadamente de acordo com a previsão de demanda para os próximos períodos.

Sem embargo, ainda há uma demanda forte da coordenação da cooperativa por formação e ferramentas que contribuam para uma gestão mais profissional, transparente e eficiente. Os agricultores não têm tradicionalmente a preocupação em formar-se para gerir sua produção. Habituados a estar dependentes dos atravessadores, que exploram o máximo possível seu poder de monopsônio, os produtores assumem uma cultura de colher e procurar vender ao preço que lhe é imposto. Portanto, um processo profundo e contínuo de formação permitirá uma capacidade de transformação dessa realidade e uma maior capacidade dos camponeses de interferir nas dinâmicas de relação ao longo da sua cadeia produtiva.

Assim, em um caminhar longo e trabalhoso, a Coopaterra tem conseguido estruturar-se nos dois primeiros eixos que são exigidos para o sonho da agroindústria. Inclusive, essas experiências já tem suscitado a discussão sobre o tipo de beneficiamento que deve ser priorizado na indústria; algo mais direcionado para o aipim, principal produto do assentamento Terra Prometida, ou uma proposta de processamento mínimo, que permita o processamento de produtos diversos vindo dos cinco territórios produtivos ligados à cooperativa.

Porém, ainda há o desafio de se ter o conhecimento técnico necessário para a elaboração do projeto de agroindústria. Com o apoio do MST e de grupos de universidades, a cooperativa tem conseguido mobilizar alguns técnicos que colaboram na elaboração de projetos, não apenas para o Terra Forte, mas também a outros editais. Entretanto, a exigência de detalhamento técnico é muito grande e tem sido algo constatado e contestado por diferentes grupos em diferentes regiões do 
Revista Tecnologia e Sociedade, Curitiba, v. 11, n. 22, 2015

Edição Especial XII Encontro Nacional de Engenharia e Desenvolvimento Social

ISSN (versão online): 1984-3526

ISSN (versão impressa): 1809-0044

país. Uma análise minuciosa das exigências do edital mostram que, na realidade, para a elaboração do projeto é necessária a constituição de uma equipe multidisciplinar e altamente qualificada.

Nesse sentido, o Soltec/UFRJ, que é um grupo do Centro de Tecnologia, originado na engenharia, tem tentado servir como ponte para as diversas demandas que aparecem para a elaboração de projetos. Mesmo dentro da engenharia, são necessários conhecimentos de engenharia de produção, civil, química, mecânica. Assim, é indispensável, para qualquer empreendimento de assentamento da reforma agrária que queira acessar o Terra Forte, conseguir mobilizar profissionais dessas diferentes áreas para a construção dessas projetos. Vale destacar que o INCRA sabe dessas dificuldades e tem tentado conseguir viabilizar técnicos que possam suprir essas lacunas. Entretanto, a exigência burocrática para aprovação do financiamento é maior e, na maioria das vezes, faz com que esse esforço não seja suficiente.

A Coopaterra tem em seus planos o objetivo de concorrer ao financiamento do Terra Forte na segunda chamada, que tem previsão de abertura para o segundo semestre de 2015. Ainda é preciso avançar muito na estruturação da cooperativa para que ela esteja pronta para receber esse apoio. Entretanto, percebe-se nitidamente seu avanço e a vontade de seus cooperados de fazer uma experiência sólida de cadeia produtiva solidária através do empreendimento. Resta saber se os apoios que a cooperativa recebe hoje serão suficientes para dar conta das exigências do edital.

\section{CONSIDERAÇÕES FINAIS}

Um dos maiores desafios para a construção de uma autêntica economia solidária, a partir da economia de resistência ativa dos movimentos sociais, está no fato de estar inserida em uma sociedade contraditória, marcada historicamente por relações sociais e de produção capitalistas. No entanto, esse conjunto de relações é hegemônico e não totalizante. A história de lutas dos trabalhadores demonstrou ser utópica a pretensão de incorporar todas as relações societais em uma lógica de subordinação do trabalho ao capital. Houve, há e sempre haverá movimentos de resistência. 
Revista Tecnologia e Sociedade, Curitiba, v. 11, n. 22, 2015

Edição Especial XII Encontro Nacional de Engenharia e Desenvolvimento Social

ISSN (versão online): 1984-3526

ISSN (versão impressa): 1809-0044

Por outro lado, a sociedade de hoje, que convive com a hegemonia da economia capitalista e com a gênese de um novo tipo de economia, é herdeira de deficiências educacionais e tem que lidar com comportamentos individuais formados em contextos autoritários, preconceituosos e burocráticos, cuja cultura predominante está fundamentada na subordinação. Por isso, enfrentar os desafios de forma objetiva, amadurecendo seus conhecimentos e culturas de grupo, buscando desenvolver a coesão social através da responsabilização de cada um dos indivíduos para o desenvolvimento do projeto coletivo, torna-se estratégico para ampliar a capacidade de resistência dessas iniciativas que pretendem ser plenamente autogestionárias.

A cada dia novos desafios surgem para os trabalhadores que se veem obrigados a desenvolverem suas potencialidades profissionais historicamente impedidos pelas relações de trabalho e de produção despóticas praticadas nas empresas capitalistas. Seguindo essa linha de raciocínio, a formação continuada e integrada torna-se central para ampliar a capacidade de resistência ativa dos trabalhadores na organização de seus empreendimentos coletivos.

Esta formação deve ocorrer nos planos: a) administrativo, utilização eficiente e eficaz das ferramentas de gestão; b) técnico, desenvolver com competência a gestão do trabalho nos processos de produção e de trabalho; c) político, aprofundar a questão da transmissão e troca de saberes entre trabalhadores associados, introduzir a politecnia nos processos, atuar nos movimentos sociais de resistência, contribuir para construir uma reserva estratégica para mudança no modo de produção vigente; e d) humanista, aprofundar o debate sobre valores humanitários.

Levando-se em consideração estas características pode-se verificar que o maior risco para esses empreendimentos solidários é entrar no jogo da banalização dos princípios duramente construídos, buscando seu crescimento pela via da competição a qualquer custo com os empreendimentos solidários ou com as empresas capitalistas. Abrir mão de princípios para garantir a concorrência e não o desenvolvimento da (inter) cooperação e do crescimento dos movimentos sociais por melhores políticas públicas, significa não compreender que essas experiências populares têm também como importância mostrar ser possível o crescimento de formas democráticas de organização coletiva do trabalho e da produção. 
Revista Tecnologia e Sociedade, Curitiba, v. 11, n. 22, 2015

Edição Especial XII Encontro Nacional de Engenharia e Desenvolvimento Social

ISSN (versão online): 1984-3526

ISSN (versão impressa): 1809-0044

Trata-se ainda de poucas experiências, algumas com mais de vinte anos de atividades contínuas, que servem como referência para outros trabalhadores terem a compreensão de que é possível o rompimento com a cultura da subalternidade e da suposta necessidade de uma gerência científica que ordene aos trabalhadores o que cada um deve cumprir, um dos pilares fundamentais da ideologia capitalista. É mister estar atentos aos riscos de perda da identidade camponesa e ao perigo de se tornarem pequenos empresários rurais competitivos entre si e com os empresários capitalistas. Faz-se necessária uma problematização contínua sobre a importância de não praticar o assalariamento do trabalhador, a organização taylorista no controle do trabalho, o crescimento econômico a qualquer preço, e, principalmente, os problemas das alianças estratégicas com grande capital, que representam a proposta de uma outra economia.

O empoderamento que a agroindustrialização fomentada pelo Programa Terra Forte pode aportar aos cooperados que atuam de forma coletiva faz vislumbrar uma política pública que enfrente questões seculares ligadas à agricultura familiar no Brasil. Há um discurso capcioso de que os pequenos produtores são hábeis e aptos para executarem as atividades produtivas primarias, mas que seu beneficiamento e consequente agregação de valor, a comercialização, isto é, a gestão do negócio no interior de uma complexa cadeia produtiva, deve ser delegado a outros atores, dotados de capacidade científica e negocial para 'tocarem' o negócio. Esse discurso dá ensejo à atuação dos atravessadores, dos monopólios e monopsônios ao longo das cadeias produtivas, levando à assimetria de poder de negociação, e relegando aos pequenos produtores rurais uma fração ínfima do valor agregado na produção, restando frustração e angústia como desdobramento do resultado operacional. Exige-se, nesse sentido, um conjunto de ações no âmbito da uma grande política que, se levados a cabo, com a seriedade e organização requeridas, pode significar uma alteração no panorama das relações de poder por tantas décadas reeditadas.

Diante desse quadro apresentado sobre a perspectiva de expansão das agroindústrias nos assentamentos de reforma agrária no Brasil, emerge o debate teórico entre distintas percepções acerca da orientação de gestão nas cooperativas. Se por um lado a vertente teórica que reflete sobre o cooperativismo tradicional ou empresarial defende que as cooperativas, ao se desenvolverem, devem ajustar-se à mesma lógica da empresa capitalista, via adoção sistemática dos postulados da 
Revista Tecnologia e Sociedade, Curitiba, v. 11, n. 22, 2015

Edição Especial XII Encontro Nacional de Engenharia e Desenvolvimento Social

ISSN (versão online): 1984-3526

ISSN (versão impressa): 1809-0044

competição globalizada. Por outro, a vertente teórica ligada às cooperativas populares oriundas de movimentos sociais defende que estas se desenvolvam economicamente, mas mantendo a autogestão e a democracia interna em seu interior, impondo a racionalidade social à racionalidade técnica.

Para que as potencialidades de uma comunidade possam alavancar 0 desenvolvimento coletivo, os atores devem estar unidos na ajuda mútua e no controle social de meios essenciais de produção e distribuição. Neste sentido, o desenvolvimento da cooperação, da democracia, do controle social e da autonomia é fundamental e deve estar, sempre que possível, presente em todos os elos de uma cadeia, formando cadeias produtivas solidárias.

\section{REFERÊNCIA}

ANSOLINE, T. A.. Ampliação da produção de piscicultura - Cooperativa de produção agropecuária união do oeste - Cooperunião. 2011. Trabalho de Conclusão de Curso. Instituto Federal do Paraná, Curitiba, 2011.

BNDES. Pronaf $\quad$ Agroindústria. 2015.2 Disponível em: <http://www.bndes.gov.br/SiteBNDES/bndes/bndes_pt/Institucional/Apoio_Financeiro/Progra mas_e_Fundos/pronaf_agroindustria.html>. Acesso em: 25 de mar. 2015.

CHIARIELLO, C. L.. Análise da gestão de cooperativas rurais tradicionais e populares: estudo de casos na Cocamar e Copavi. 2008. Dissertação (Mestrado em Engenharia de Produção) - Programa de Pós-graduação em Engenharia de Produção, Universidade Federal de São Carlos, São Carlos, 2008.

CHRISTOFFOLI, P. I.. Eficiência econômica e gestão democrática nas cooperativas de produção coletiva do M.S.T.. 1998. Trabalho de Conclusão de Curso (Especialização) UNISINOS, São Leopoldo, 1998.

CONCRAB. Cooperativas de produção: Questões Práticas. São Paulo, abril. 1996.

DAL RI, N.; VIEITEZ, C. G..Educação democrática e trabalho associado no movimento dos trabalhadores rurais sem terra e nas fábricas de autogestão. Ícone: São Paulo, 2008.

COOPERAÇÃO E APOIO A PROJETOS DE INSPIRAÇÃO ALTERNATIVA (CAPINA). Puxando o fio da meada: Viabilidade econômica de empreendimentos associativos. Rio de Janeiro: CAPINA, 1998.

EID, F.; PIMENTEL, A. E. B.; SEVERINO, M. R.; SANTOS, C dos. Cadeias produtivas sob controle de famílias cooperadas do M.S.T.. 2006, Quito. In: VII Congresso Latinoamericano de Sociologia Rural. Anais...Quito: ALASRU, 2006. Pp.1-18.

GONÇALVES, A. N.. Estudo de viabilidade na produção de iogurte orgânico.2011. Trabalho de Conclusão de Curso. Instituto Federal do Paraná, Curitiba, 2011. 
Revista Tecnologia e Sociedade, Curitiba, v. 11, n. 22, 2015

Edição Especial XII Encontro Nacional de Engenharia e Desenvolvimento Social

ISSN (versão online): 1984-3526

ISSN (versão impressa): 1809-0044

HENRIQUES, F.C. et alli. Empresas Recuperadas por Trabalhadores no Brasil. Rio de Janeiro: Multifoco, 2013.

MANCE, E. A.. Como organizar redes solidárias. Rio de Janeiro: IFIL / FASE / DP\&A, 2003.

MDA - MINISTÉRIO DO DESENVOLVIMENTO AGRÁRIO, BRASIL. Intensificadas ações no assentamento Bela Vista do Chibarro (SP). Notícia de 22/10/2007. Disponível em: http://www.mda.gov.br/portal/index/show/index/cod/134/codinterno/14716 acesso em 15/05/2008.

METELLO, D. G.. Os Benefícios da Associação em cadeias produtivas solidárias: $O$ caso da Justa Trama Cadeia solidária do algodão agroencológica. 2006. Dissertação (Mestrado em Engenharia de Produção) - Universidade Federal do Rio de Janeiro, 2007

MIOR, Liuz C. Agricultores familiares, agroindústrias e redes de desenvolvimento rural. Chapecó: Argos, 2005.

MOURA, I. F.. Assentamentos rurais: agregação de valor e comercialização: o caso do Assentamento Santa Maria (Paranacity-PR).2006. Dissertação (Mestrado em Economia) Instituto de Economia, Universidade Estadual de Campinas, Campinas, 2006.

PIMENTEL, Andréa E. B. Assentamentos de Reforma Agrária na região do Pontal do Paranapanema e seus impactos econômicos e sociais. Tese de Doutorado. Programa de Pós-Graduação em Engenharia de Produção, São Carlos: UFSCar, 2004. 267 p.

RUTKOWSKI, J. Sustentabilidade de empreendimentos econômicos: uma abordagem na Engenharia de Produção. 2008. Tese (Doutorado em Engenharia de Produção) - Ufscar, 2008.

SCHNEIDER, Sergio; CAZELLA, Ademir; MATTEI, Lauro. Histórico, caracterização e dinâmica recente do Pronaf-Programa Nacional de Fortalecimento da Agricultura Familiar. In: SCHNEIDER, Sergio; SILVA, Marcelo K.; MARQUES, Paulo E.M. (Orgs.) Políticas públicas e participação social no Brasil rural. Porto Alegre (RS): Editora da UFRGS, 2004. 274 p.21-49.

SEVERINO. M. R.. Organização e processos de trabalho em cooperativas do M.S.T.: debate teórico no contexto da empresa capitalista e da economia solidária. 2006. Dissertação (Mestrado em Engenharia de Produção) - Programa de Pós-graduação em Engenharia de Produção, Universidade Federal de São Carlos, São Carlos, 2006.

THIOLLENT, M. Metodologia da pesquisa-ação. 18. ed. São Paulo: Cortez, 2011.

VAZZOLER. M. R.. Cooperativismo em assentamentos de reforma agrária: a sobrevivência de cooperativas do M.S.T. no contexto capitalista. 2004. Tese (Doutorado em Engenharia de Produção) - Programa de Pós-graduação em Engenharia de Produção, Universidade Federal de São Carlos, São Carlos, 2004. 